\title{
ANALISIS FAKTOR-FAKTOR YANG MEMPENGARUHI VOLUME EKSPOR BIJI KAKAO INDONESIA KE MALAYSIA
}

\section{Ilma Yuni Rosita, Lilis Imamah Ichdayati* dan Rizki Adi Puspita Sari}

\begin{abstract}
ABSTRAK
Penelitian ini bertujuan untuk menganalisis faktor-faktor yang mempengaruhi volume ekspor kakao Indonesia ke Malaysia. Regresi linear dan kuadrat biasa (OLS) digunakan untuk menganalisis data time series dari tahun 2005 hingga 2013. Berdasarkan analisis, diperoleh bahwa faktor-faktor yang secara signifikan mempengaruhi volume ekspor kakao Indonesia ke Malaysia dengan tingkat signifikansi $(\alpha)$ lima persen adalah harga riil ekspor kakao Indonesia ke Malaysia dan harga riil biji kakao pasar internasional.
\end{abstract}

Kata kunci: volume ekspor, biji kakao, Indonesia, Malaysia, harga ekspor

\begin{abstract}
This study aims to analyze the factors that affect the volume of Indonesian cocoa exports to Malaysia. Multiple linear regression and ordinary least squares (OLS) were employed to analyze time series of data from 2005 until 2013. Based on the analysis, it is obtained that factors that significantly effect the volume of Indonesian cocoa exports to Malaysia with a significance level $(\alpha)$ five percent are the real prices of Indonesian cocoa exports to Malaysia and the real prices of cocoa beans the international market.
\end{abstract}

Keywords: export volumes, cocoa beans, Indonesia, Malaysia, export prices

\section{PENDAHULUAN}

Kakao merupakan salah satu komoditas pertanian dalam sektor perkebunan yang menjadi andalan ekspor Indonesia. Selain sebagai penyedia lapangan pekerjaan, sumber pendapatan petani dan devisa negara, ekspor kakao juga mampu meningkatkan pengembangan wilayah serta pengembangan agribisnis dan agro industri di
Indonesia. Oleh karena itu, kakao menjadi salah satu jenis komoditas ekspor yang memiliki potensi strategis dalam membangun perekonomian negara pada skala nasional.

Pengembangan wilayah dalam sektor perkebunan kakao dapat dilihat dengan bertambahnya luas areal perkebunan kakao di Indonesia. Menurut status pengusahaannya, perkebunan kakao Indonesia dibagi menjadi tiga bagian, yaitu perkebunan 
rakyat, perkebunan besar negara, dan perkebunan besar swasta. Perkebunan rakyat sendiri telah mendominasi perkebunan kakao Indonesia sebesar 94,6\% dari perkebunan kakao Indonesia, diikuti oleh perkebunan besar negara sebesar 2,8\% dari perkebunan kakao Indonesia, kemudian perkebunan besar swasta sebesar 2,6\% dari perkebunan kakao Indonesia (Direktorat Jenderal Perkebunan, 2013 dalam Wahyudi, dkk, 2015 : 14).

Perkebunan kakao hampir tersebar di seluruh pelosok Indonesia. Menurut Direktorat Jenderal Perkebunan (2013) dalam Wahyudi, dkk (2015 : 14), areal perkebunan kakao di Indonesia terpusat di Pulau
Sulawesi dengan sentra perkebunan di Sulawesi Tengah (297.572 ha), Sulawesi Selatan (282.071 ha), Sulawesi Tenggara (264.954 ha), dan Sulawesi Barat (180,585 ha) dengan kontribusi persentase lahan yang mencapai 55,3\% dari lahan kakao nasional. Diikuti Sumatera Barat sebesar 7,72\%, Aceh 5,8\%, Sumatera Utara 4,52\%, Lampung 3,7\%, dan wilayah Indonesia lainnya sebesar 22,93\%. Tabel 1 berikut menunjukkan data perkembangan luas areal dan perkembangan produksi kakao (perkebunan rakyat, perkebunan negara, dan perkebunan swasta) di Indonesia yang mengalami peningkatan.

Tabel 1. Perkembangan Luas Areal dan Produksi Kakao Indonesia Tahun 2004 2013

\begin{tabular}{|c|c|c|c|c|}
\hline Tahun & $\begin{array}{c}\text { Luas Areal } \\
(\mathbf{H a})\end{array}$ & $\begin{array}{c}\text { Pertumbuhan } \\
(\boldsymbol{\%})\end{array}$ & $\begin{array}{c}\text { Produksi } \\
(\mathbf{T o n})\end{array}$ & $\begin{array}{c}\text { Pertumbuhan } \\
(\boldsymbol{\%})\end{array}$ \\
\hline 2004 & 1.090 .960 & 0 & 691.704 & 0 \\
\hline 2005 & 1.167 .046 & 6,52 & 748.828 & 7,63 \\
\hline 2006 & 1.320 .820 & 11,64 & 769.388 & 2,67 \\
\hline 2007 & 1.379 .279 & 4,24 & 740.006 & $-3,97$ \\
\hline 2008 & 1.425 .217 & 3,22 & 803.594 & 7,91 \\
\hline 2009 & 1.587 .136 & 10,20 & 809.583 & 0,74 \\
\hline 2010 & 1.650 .621 & 3,85 & 837.918 & 3,38 \\
\hline 2011 & 1.732 .641 & 4,73 & 712.231 & $-17,65$ \\
\hline 2012 & 1.774 .463 & 2,36 & 740.513 & 3,82 \\
\hline 2013 & 1.740 .612 & $-1,94$ & 720.862 & $-2,73$ \\
\hline Rata-Rata & $1.486879,50$ & 4,48 & $757.462,70$ & 0,18 \\
\hline
\end{tabular}

Sumber: Direktorat Jenderal Perkebunan Kementerian Pertanian RI (2014:3) (Diolah)

Rata-rata produksi biji kakao Indonesia dalam sepuluh tahun yang cukup tinggi menempatkan Indonesia ke dalam lima besar negara produsen biji kakao terbesar di dunia. Berdasarkan data dari ICCO (International Cocoa Organization) (2013) dalam Wahyudi, dkk (2015 :
10) menunjukkan bahwa negara Indonesia menempati peringkat ketiga sebagai penghasil biji kakao terbesar di dunia setelah Pantai Gading (Afrika) menempati peringkat pertama dan Ghana (Afrika) menempati peringkat kedua. Kontribusi pasokan biji kakao dari ketiga negara tersebut 
mencapai $68 \%$ dari kebutuhan kakao di dunia dan $10,6 \%$ kakao dunia berasal dari Indonesia. Alasan kenapa para petani kakao di Indonesia tidak melakukan fermentasi biji kakao adalah harga biji kakao fermentasi dan tanpa fermentasi tidak berbeda jauh.

Tabel 2 berikut menunjukkan data total volume dan nilai ekspor biji kakao yang dilakukan oleh Indonesia ke seluruh negara tujuan ekspor kakao.

Tabel 2. Volume dan Nilai Ekspor Biji Kakao Indonesia Tahun 2004 - 2013

\begin{tabular}{|c|c|c|c|c|}
\hline Tahun & $\begin{array}{c}\text { VolumeEkspor } \\
\text { (Ton) }\end{array}$ & $\begin{array}{c}\text { Pertumbuhan } \\
(\boldsymbol{\%})\end{array}$ & $\begin{array}{c}\text { NilaiEkspor } \\
\text { (000US\$) }\end{array}$ & $\begin{array}{c}\text { Pertumbuhan } \\
(\boldsymbol{\%})\end{array}$ \\
\hline 2004 & $275.484,49$ & 0 & $369.863,00$ & 0 \\
\hline 2005 & $367.425,78$ & 25,02 & $467.827,36$ & 20,94 \\
\hline 2006 & $490.777,60$ & 25,13 & $619.016,76$ & 24,42 \\
\hline 2007 & $379.829,20$ & $-29,21$ & $622.600,38$ & 0,58 \\
\hline 2008 & $380.512,86$ & 0,17 & $854.584,78$ & 27,15 \\
\hline 2009 & $439.305,32$ & 13.38 & $1.087 .484,65$ & 21,42 \\
\hline 2010 & $432.326,85$ & -1.61 & $1.190 .739,69$ & 8,67 \\
\hline 2011 & $210.066,99$ & -105.80 & $614.496,35$ & $-93,77$ \\
\hline 2012 & $163.500,82$ & -28.48 & $384.829,79$ & $-59,68$ \\
\hline 2013 & $188.420,19$ & 13.23 & $446.094,72$ & 13,73 \\
\hline $\begin{array}{c}\text { Rata- } \\
\text { Rata }\end{array}$ & $332.765,01$ & -9.79 & $665.753,75$ & $-3,65$ \\
\hline
\end{tabular}

Sumber: Badan Pusat Statistika Diolah Pusat Data dan Informasi Kementerian Perdagangan RI (2016 :1) (Diolah)

Berdasarkan data pada Tabel 2 menunjukkan bahwa pada tahun 2005 volume ekspor biji kakao Indonesia mengalami kenaikan sebesar $25,02 \%$. Kenaikan volume ekspor tersebut sesuai dengan kenaikan produksi biji kakao Indonesia dimana pada tahun 2005 produksi biji kakao Indonesia mengalami peningkatan sebesar 7,63\% (Tabel 1). Bertambahnya total produksi biji kakao Indonesia semakin membuat tingginya minat petani kakao untuk mengekspor hasil pertanian biji kakao mereka sehingga dapat meningkatkan volume ekspor biji kakao Indonesia.

Besarnya minat petani kakao untuk mengekspor hasil pertanian kakao semakin didukung oleh Peraturan Pemerintah Nomor 46 Tahun 2003. Setelah ditetapkannya PPN sebesar $10 \%$ oleh pemerintah, pada tahun 2004 volume ekspor biji kakao Indonesia mengalami peningkatan. Meningkatnya volume ekspor biji kakao Indonesia yang mengakibatkan berkurangnya bahan baku dalam negeri, maka pemerintah menghapuskan kebijakan PPN 10\% terhadap komoditas kakao.

Melalui kebijakan bea keluar yang disahkan oleh Kementerian Keuangan, pemerintah berharap ekspor kakao lebih banyak dalam bentuk olahan. Selain bertujuan untuk mengembangkan industri pengolahan kakao dalam negeri, adanya kebijakan bea keluar juga bertujuan untuk menekan volume ekspor biji kakao Indonesia.Ada beberapa negara yang menjadi tujuan utama ekspor biji kakao Indonesia. Negara-negara tersebut meliputi Amerika Serikat, Malaysia, Singapura, China, dan lainlain. 
Tabel 3. Volume Ekspor (Ton) Biji Kakao Indonesia Berdasarkan Negara Tujuan Utama Tahun 2004 - 2013

\begin{tabular}{|c|c|c|c|c|c|}
\hline $\begin{array}{c}\text { Tahun/ } \\
\text { Negara }\end{array}$ & $\begin{array}{c}\text { Amerika } \\
\text { Serikat }\end{array}$ & China & Malaysia & Singapura & Lainnya \\
\hline 2004 & $84.007,0$ & $5.474,6$ & $125.384,3$ & $31.570,3$ & $29.048,4$ \\
\hline 2005 & $107.630,5$ & $15.830,1$ & $156.057,0$ & $30.093,9$ & $57.814,2$ \\
\hline 2006 & $131.738,5$ & $18.240,9$ & $193.173,5$ & $43.976,5$ & $103.648,2$ \\
\hline 2007 & $53.224,4$ & $20.746,1$ & $183.172,1$ & $43.683,5$ & $79.003,1$ \\
\hline 2008 & $53.689,7$ & $15.902,5$ & $209.408,5$ & $45.157,5$ & $56.354,7$ \\
\hline 2009 & $120.304,0$ & $7.122,6$ & $183.539,1$ & $55.889,3$ & $72.450,3$ \\
\hline 2010 & $89.306,5$ & $15.317,9$ & $203.847,7$ & $53.932,2$ & $69.922,5$ \\
\hline 2011 & $9.765,9$ & $7.637,0$ & $141.104,6$ & $33.793,0$ & $17.766,5$ \\
\hline 2012 & 143,3 & $5.751,5$ & $102.350,1$ & $39.707,4$ & $15.548,6$ \\
\hline 2013 & $7.208,7$ & $8.320,0$ & $134.774,4$ & $32.350,2$ & $5.766,9$ \\
\hline $\begin{array}{c}\text { Rata- } \\
\text { Rata }\end{array}$ & $65.701,8$ & $12.034,3$ & $163.281,1$ & $41.015,4$ & $50.732,3$ \\
\hline
\end{tabular}

Sumber: Badan Pusat Statistika Diolah Pusat Data dan Informasi Kementerian Perdagangan RI (2016:1)

Berdasarkan data pada Tabel 3 menunjukkan bahwa selama kurun waktu tahun 2004 - 2013 volume ekspor biji kakao Indonesia didominasi oleh negara Malaysia. Rata-rata volume ekspor biji kakao Indonesia ke Malaysia dalam kurun waktu 2004 - 2013 sebesar 163.281,1 ton, lebih besar dibandingkan dengan volume ekspor biji kakao ke negaranegara lain. Data tersebut menunjukkan bahwa Malaysia merupakan konsumen terbesar komoditas biji kakao yang dihasilkan Indonesia.

Meskipun negara Malaysia menjadi negara tujuan utama dan terbesar ekspor biji kakao Indonesia, namun volume biji kakao yang diekspor Indonesia ke Malaysia mengalami kecenderungan berfluktuatif dari tahun ke tahun.

Volume ekspor biji kakao Indonesia ke Malaysia yang berfluktuatif menunjukkan bahwa ada faktor-faktor yang menyebabkan permintaan Malaysia terhadap biji kakao
Indonesia mengalami perubahan di setiap tahunnya.

\section{Rumusan Masalah}

Berdasarkan uraian pada latar belakang, maka dapat dirumuskan beberapa permasalahan yaitu sebagai berikut:

1. Apa saja faktor - faktor yang mempengaruhi volume eskpor biji kakao Indonesia ke Malaysia periode 2005 - 2013?

2. Seberapa besar pengaruh factorfactor tersebut terhadap volume ekspor biji kakao Indonesia ke Malaysia periode 2005-2013?

\section{METODE PENELITIAN}

\section{Waktu Penelitian}

Penelitian tentang faktor-faktor yang mempengaruhi volume ekspor biji kakao Indonesia Ke Malaysia ini dilakukan dengan cara pengambilan data dari beberapa lembaga yang terkait dengan penelitian. Lembagalembaga tersebut meliputi Kementerian Pertanian Republik 
Indonesia, Kementerian Perdagangan Republik Indonesia, Badan Pusat Statistik (BPS) Republik Indonesia, Bank Indonesia (BI), International Cocoa Organization (ICCO), uncomtrade, dan lembaga-lembaga lainnya yang menunjang penelitian, serta penelitian-penelitian terdahulu. Penelitian ini dilaksanakan selama tiga bulan, yaitu bulan Oktober sampai bulan Desember 2015.

\section{Jenis dan Sumber Data}

Data yang digunakan dalam penelitian tentang faktor-faktor yang mempengaruhi volume eskpor biji kakao Indonesia ke Malaysia berdasarkan jenisnya yaitu menggunakan data kuantitatif. Data kuantitatif dalam penelitian ini merupakan data yang didapatkan dari fakta dan informasi yang dapat diukur berupa angka-angka. Data kuantitatif yang digunakan dalam penelitian ini terdiri dari data volume ekspor biji kakao Indonesia ke Malaysia, produksi biji kakao Indonesia, volume impor biji kakao Malaysia, nilai tukar rupiah terhadap dollar Amerika Serikat, harga riil ekspor biji Indonesia ke Malaysia, harga riil pasar internasional biji kakao, dan dummy tarif ekspor biji kakao Indonesia ke Malaysia.

Berdasarkan sumbernya, data yang digunakan dalam penelitian tentang analisis faktor-faktor yang mempengaruhi volume ekspor biji kakao Indonesia ke Malaysia yaitu menggunakan data sekunder.Data sekunder adalah data yang diperoleh dari lembaga-lembaga atau instansiinstansi tertentu atau data dari sumber kedua (Suyatno dan Sutinah, 2005:56). Adapun data-data yang digunakan dan sumber data yang terkait dalam penelitian ini dapat dilihat pada Tabel 4 berikut.

Tabel 4. Data dan Sumber Data Penelitian

\begin{tabular}{|c|l|l|}
\hline No & \multicolumn{1}{|c|}{ Data SekunderPenelitian } & \multicolumn{1}{c|}{ Sumber Data } \\
\hline 1. & $\begin{array}{l}\text { Volume ekspor biji kakao Indonesia } \\
\text { ke Malaysia (000ton) }\end{array}$ & $\begin{array}{l}\text { Badan Pusat Statistik Diolah } \\
\text { Pusat Data dan Informasi } \\
\text { Kementerian Perdagangan RI }\end{array}$ \\
\hline 2. & $\begin{array}{l}\text { Produksi biji kakao Indonesia (000 } \\
\text { ton) }\end{array}$ & $\begin{array}{l}\text { Kementerian Pertanian Republik } \\
\text { Indonesia }\end{array}$ \\
\hline 3. & $\begin{array}{l}\text { Volume impor biji kakao Malaysia } \\
(000 t o n)\end{array}$ & $\begin{array}{l}\text { Uncomtrade dengan mengakses } \\
\text { website } \text { www.comtrade.un.org }\end{array}$ \\
\hline 4. & $\begin{array}{l}\text { Nilai tukar riil rupiah terhadap dollar } \\
\text { Amerika Serikat(Rp/US\$) }\end{array}$ & $\begin{array}{l}\text { Bank Indonesia dengan } \\
\text { mengakses website www.bi.go.id }\end{array}$ \\
\hline 5. & $\begin{array}{l}\text { Hargariil ekspor biji kakao } \\
\text { Indonesia ke Malaysia (US\$/000 ton) }\end{array}$ & $\begin{array}{l}\text { Badan Pusat Statistik Diolah } \\
\text { Pusat Data dan Informasi } \\
\text { Kementerian Perdagangan RI }\end{array}$ \\
\hline
\end{tabular}




\begin{tabular}{|l|l|l|}
\hline 6. & $\begin{array}{l}\text { Harga riil pasar internasional biji } \\
\text { kakao(US\$/000 ton) }\end{array}$ & $\begin{array}{l}\text { Internasional Cocoa Organization } \\
\text { (ICCO) dengan mengakses } \\
\text { website } \text { www.icco.org }\end{array}$ \\
\hline
\end{tabular}

\section{Metode Pengumpulan Data}

Metode pengumpulan data adalah cara yang dapat digunakan dalam penelitian untuk mengumpulkan data. Penelitian tentang analisis faktor-faktor yang mempengaruhi volume ekspor biji kakao Indonesia ke Malaysia ini menggunakan data sekunder dengan data deret waktu (time series) pada skala triwulan dari tahun 2005 hingga tahun 2013 (9 tahun). Metode yang digunakan dalam pengumpulan data pada penelitian ini yaitu teknik pengumpulan data dengan cara mengkaji dan memahami sumbersumber data yang dibutuhkan dalam penelitian. Mengunjungi lembagalembaga yang terkait dalam penelitian ini, seperti Kemeterian Pertanian RI, Kementerian Perdagangan RI, dan Badan Pusat Statistik (BPS) RI. Pengumpulan data dalam penelitian ini juga menggunakan media internet meliputi website Bank Indonesia (BI) yaitu www.bi.go.id, website International Cocoa Organization (ICCO) yaitu www.icco.org, dan website uncomtrade yaitu www.comtrade.un.org, serta mengunjungi website-website yang terkait untuk menunjang penelitian.

\section{Metode Pengolahan Data dan Analisis Data}

Data-data yang diperoleh selama penelitian diolah dengan menggunakan alat analisis kualitatif berupa analisis deskriptif dan alat analisis kuantitatif berupa analisis regresi linear berganda. Data-data yang dibutuhkan untuk analisis kuantitatif dalam penelitian tentang analisis faktor-faktor yang mempengaruhi volume ekspor biji kakao Indonesia ke Malaysia meliputi variabel-variabel yang digunakan dalam penelitian.

Metode pengolahan data berdasarkan variabel-variabel dalam penelitian ini secara lebih rinci sebagai berikut:

1. Data volume ekspor biji kakao Indonesia ke Malaysia dengan satuan ribu ton (000 ton) dalam skala triwulan kurun waktu tahun 2005 sampai 2013.

2. Data produksi biji kakao Indonesia dengan satuan ribu ton (000 ton) dalam skala triwulan kurun waktu tahun 2005 sampai 2013. Berdasarkan data dari Kementerian Pertanian Republik Indonesia, data produksi biji kakao Indonesia yang tersedia merupakan data tahunan, sehingga diasumsikan untuk mendapatkan data triwulan maka diambil rata-rata triwulan dalam setahun.

3. Data volume impor biji kakao Malaysia dengan satuan ribu ton (000 ton) dalam skala triwulan kurun waktu tahun 2005 sampai 2013. Berdasarkan data dari uncomtrade, data volume impor biji kakao yang tersedia merupakan data tahunan, sehingga diasumsikan untuk mendapatkan data triwulan maka diambil rata-rata triwulan dalam satu tahun.

4. Data nilai tukar riil rupiah terhadap dollar Amerika Serikat dengan satuan rupiah per US\$ 
(Rp/US\$) dalam kurun waktu triwulan tahun 2005 sampai 2013.

Nilai tukar riil adalah harga relatif dari barang-barang kedua negara, yang menyatakan tingkat di mana kita dapat memperdagangkan barang- barang dari suatu negara untuk barang-barang dari negara lain (Rahardja dan Manurung, 2008:307).

5. Harga riil ekspor biji kakao Indonesia ke Malaysia dengan satuan US\$ per ribu ton (US $\$ / 000$ ton) dalam kurun waktu triwulan tahun 2005 sampai 2013. Harga ekspor biji kakao Indonesia ke Malaysia diperoleh dari pembagian nilai ekspor biji kakao Indonesia ke Malaysia (US\$) dengan volume ekspor biji kakao Indonesia ke Malaysia (000 ton). Sedangkan harga riil ekspor biji kakao Indonesia ke Malaysia diperoleh dari pembagian harga ekspor biji kakao Indonesia ke Malaysia dengan indeks harga konsumen (Malaysia tahun dasar $2007=100)$.

6. Harga riil pasar internasional biji kakao merupakan harga biji kakao yang berlaku di pasar internasional dengan satuan US\$ per ribu ton (US\$/000 ton) dalam kurun waktu triwulan tahun 2005 sampai 2013. Harga riil internasional diperoleh dari pembagian harga internasional dengan indeks harga konsumen (Amerika Serikat tahun dasar $2007=100$ ).

7. Tarif ekspor biji kakao Indonesia ke Malaysia adalah pajak dibebankan terhadap ekspor biji kakao Indonesia ke Malaysia. Dalam penelitian ini tarif ekspor biji kakao Indonesia ke Malaysia diwakili dengan variabel dummy.
8. Indeks harga konsumen adalah ukuran biaya keseluruhan barang dan jasa yang dibeli oleh konsumen (Mankiw, 2012 : 26). Nilai indeks harga konsumen yang digunakan dalam penelitian ini meliputi indeks harga konsumen Indonesia sebagai negara pengekspor biji kakao, indeks harga konsumen Malaysia sebagai negara pengimpor biji kakao, serta indeks harga konsumen Amerika Serikat sebagai negara yang mata uangnya digunakan sebagai alat transaksi di pasar internasional.

\section{Analisis Deskriptif}

Analisis deskriptif merupakan analisis yang dilakukan dengan cara memberikan penggambaran. Tujuan dari analisis deskriptif adalah untuk memberikan gambaran secara sistematis dan akurat mengenai hubungan antara fenomena yang diteliti. Fenomena-fenomena yang dideskripsikan dalam penelitian tentang analisis faktor-faktor yang mempengaruhi volume ekspor biji kakao Indonesia ini berupa perkembangan-perkembangan biji kakao di negara produsen (Indonesia), meliputi perkembangan luas areal kakao Indonesia, perkembangan produksi kakao Indonesia, perkembangan harga biji kakao, perkembangan ekspor biji kakao Indonesia, dan perkembangan tarif ekspor biji kakao di Indonesia. Kemudian mendeskripsikan fenomena perkembangan- perkembangan biji kakao dunia (pasar internasional), meliputi perkembangan luas areal kakao dunia, perkembangan produksi kakao dunia, perkembangan ekspor biji kakao dunia, dan perkembangan impor biji kakao dunia. Mendeskripsikan fenomena 
perkembangan-perkembangan biji kakao di negara konsumen (Malaysia), meliputi perkembangan produksi kakao Malaysia, perkembangan konsumsi biji kakao Malaysia, dan perkembangan impor biji kakao Malaysia.

\section{Analisis Regresi Linear Berganda}

Analisis kuantitatif yang digunakan dalam penelitian tentang analisis faktor-faktor yang mempengaruhi volume ekspor biji kakao Indonesia ke Malaysia adalah analisis regresi linear berganda. Menurut Ridwan (2010:154) regresi linear berganda adalah suatu alat analisis peramalan nilai pengaruh dua variabel bebas atau lebih terhadap variabel terikat untuk membuktikan ada atau tidaknya hubungan fungsi atau hubungan kausal antara dua variabel atau lebih dengan variabel terikat.

Ada beberapa faktor yang mempengaruhi volume ekspor biji kakao Indonesia ke Malaysia di antaranya, produksi biji kakao Indonesia, volume impor biji kakao Malaysia, nilai tukar riil rupiah terhadap dollar Amerika Serikat, harga riil ekspor biji kakao Indonesia ke Malaysia, harga riil pasar internasional biji kakao, serta dummy tarif ekspor biji kakao Indonesia ke Malaysia. Persamaan regresi linear berganda untuk mengidentifikasi faktor-faktor yang mempengaruhi volume ekspor biji kakao Indonesia ke Malaysia sebagai berikut :

$Y=\alpha+\beta 1 X 1+\beta 2 X 2+\beta 3 X 3+\beta 4 X 4+\beta 5$

$\mathrm{X} 5+\mathrm{XDXD}+\varepsilon$

Hipotesa: $\beta 1, \beta 2, \beta 4, \beta 5>0 ; \beta 3, \beta \mathrm{D}<0$

Keterangan:

$\mathrm{Y} \quad=$ Volume ekspor biji kakao Indonesia ke Malaysia

$\alpha=$ Konstanta $\beta=$ Koefisien regresi

$\mathrm{X} 1$ = Produksi biji kakao Indonesia

$\mathrm{X} 2=$ Volume impor biji kakao

Malaysia

$\mathrm{X} 3$ = Nilai tukar riil rupiah terhadap dollar Amerika Serikat

$\mathrm{X} 4=$ Harga riil ekspor biji kakao Indonesia ke Malaysia

$\mathrm{X} 5=$ Harga riil pasar internasional biji kakao

$\mathrm{XD}=$ Dummy tarif ekspor biji kakao Indonesia ke Malaysia, dummy menunjukkan perubahan pada kebijakan tarif ekspor. Angka 1 mewakili data setelah pemberlakuan tarif ekspor (tahun 2010 pada triwulan kedua sampai tahun 2013) dan angka 0 mewakili data sebelum pemberlakuan tarif ekspor (tahun 2005 sampai tahun 2010 pada triwulan pertama)

$\varepsilon=$ Error

\section{Uji Kriteria Ekonometrika (Uji Asumsi Klasik)}

Sujianto (2007) dalam Sujianto (2009:79) menyatakan model regresi linear berganda disebut model yang baik jika model tersebut memenuhi asumsi normalitas data dan terbebas dari asumsi-asumsi klasik yaitu multikolienearitas, autokolerasi, dan heteroskedastisitas.Berdasarkan

pendapat ini, uji normalitas data bukan satu-satunya cara untuk menyimpulkan model regresi berganda adalah baik. Dalam melakukan estimasi model regresi berganda maka harus memenuhi kriteria ekonometrik, yaitu kriteria yang diuji meliputi multikolinearitas, heteroskedasitas, autokorelasi, dan normalitas.

\section{Uji Statistik (Uji Hipotesis)}

Uji hipotesis dapat dilakukan dengan melakukan pengujian parameter model regresi (uji t dan uji 
F) serta pengujian koefisien determinasi (R2).

\section{Definisi Operasional}

Definisi operasional adalah suatu definisi mengenai variabel yang dirumuskan berdasarkan karakteristikkarakteristik varaibel tersebut yang dapat diamati (Azwar, 2013:74). Berikut adalah definisi operasional masing-masing variabel dalam penelitian tentang faktor-faktor yang mempengaruhi volume ekspor biji kakao Indonesia ke Malaysia:

a. Volume ekspor biji kakao Indonesia ke Malaysia yang dimaksud adalah total volume ekspor biji kakao Indonesia ke Malaysia dalam satuan ribu ton (000 ton). Data yang digunakan merupakan data triwulan (time series) selama 9 tahun dari tahun 2005 sampai tahun 2013.

b. Produksi biji kakao Indonesia adalah total keseluruhan produksi biji kakao Indonesia. Satuan yang digunakan adalah ribu ton (000 ton). Data yang digunakan merupakan data triwulan (time series) selama 9 tahun dari tahun 2005 sampai tahun 2013.

c. Volume impor biji kakao Malaysia adalah total volume impor biji kakao Malaysia dari seluruh dunia dalam satuan ribu ton (000 ton). Data yang digunakan merupakan data triwulan (time series) selama 9 tahun dari tahun 2005 sampai tahun 2013.

d. Nilai tukar riil rupiah terhadap dollar Amerika Serikat adalah nilai perbandingan mata uang rupiah terhadap dollar Amerika Serikat (US\$) yang berlaku dalam satuan Rupiah per US\$ (Rp/US\$). Data yang digunakan merupakan data triwulan (time series) selama 9 tahun dari tahun 2005 sampai tahun 2013.

e. Harga riil ekspor biji kakao ke Malaysia adalah harga biji kakao ekspor yang berlaku ke Malaysia dalam satuan US\$ per ribu ton (US\$/000 ton). Data yang digunakan merupakan data triwulan (time series) selama 9 tahun dari tahun 2005 sampai tahun 2013.

f. Harga riil pasar internasional biji kakao adalah harga biji kakao yang berlaku di pasar internasional dalam satuan US\$ per ribu ton (US\$/000 ton). Data yang digunakan merupakan data triwulan (time series) selama 9 tahun dari tahun 2005 sampai tahun 2013.

g. Tarif ekspor biji kakao Indonesia ke Malaysia adalah pajak yang dikenakan terhadap biji kakao yang diekspor ke Malaysia yang bertujuan untuk menekan volume ekspor biji kakao Indonesia ke Malaysia. Data yang digunakan merupakan data dummy tarif ekspor dengan skala triwulan (time series) selama 9 tahun dari tahun 2005 sampai tahun 2013.

\section{HASIL DAN PEMBAHASAN}

\section{Identifikasi Faktor-Faktor yang Mempengaruhi Volume Ekspor Biji Kakao Indonesia ke Malaysia Tahun 2005 - 2013}

Model volume ekspor biji kakao Indonesia ke Malaysia yang digunakan dalam penelitian ini bertujuan untuk mengetahui faktor-faktor yang mempengaruhi volume ekspor biji kakao Indonesia ke Malaysia tahun 2005 - 2013 dengan menggunakan metode Ordinary Least Square (OLS) pada program SPSS 22. Data yang digunakan dalam penelitian ini adalah deret waktu (time series) dengan skala triwulan mulai dari tahun 2005 hingga tahun 2013 (9 tahun dengan 36 data time series).

Faktor-faktor yang mempengaruhi volume ekspor biji kakao Indonesia ke Malaysia didapatkan dengan memasukkan 
variabel-variabel bebas yang diduga mempengaruhi volume ekspor biji kakao Indonesia ke Malaysia (variabel terikat). Variabel-variabel bebas yang digunakan ada enam variabel yaitu produksi biji kakao Indonesia, volume impor biji kakao Malaysia, nilai tukar riil rupiah terhadap dollar Amerika Serikat, harga riil ekspor biji kakao Indonesia ke Malaysia, harga riil pasar internasional biji kakao, dan dummy tarif ekspor biji kakao Indonesia ke Malaysia.

Model volume ekspor biji kakao Indonesia ke Malaysia terlebih dahulu dilakukan serangkaian pengujian baik pengujian secara pengujian secara ekonometrik (uji asumsi klasik) maupun statistik (uji hipotesis). Penelitian ini juga mengikutsertakan pembahasan ekonomi yang bertujuan untuk menganalisis hasil estimasi dengan keadaan yang sebenarnya. Pada uji asumsi klasik dianalisis dengan menggunakan uji multikolinearitas, uji heteroskedastisitas, uji autokorelasi, dan juga uji normalitas. Pada uji hipotesis dianalisis menggunakan uji simultan (uji F), uji parsial (uji t), dan uji koefisien determinasi (R2).

\section{Hasil Pengujian Asumsi Klasik}

Pengujian asumsi klasik bertujuan untuk mengetahui ada atau tidaknya penyimpangan asumsi klasik dalam model volume ekspor biji kakao Indonesia ke Malaysia. Uji asumsi klasik meliputi uji multikolinearitas, uji heteroskedastisitas, uji autokorelasi, serta uji normalitas.

\section{Uji Multikolinearitas}

Salah satu cara dalam mendeteksi ada atau tidaknya multikolinearitas dalam suatu model adalah dengan melihat nilai Variance Inflation Factor (VIF). Apabila nilai VIF > 10, maka dapat disimpulkan terdapat masalah multikolinearitas. Hasil uji multikolinearitas model volume ekspor biji kakao Indonesia ke Malaysia dapat dilihat pada Tabel 7 berikut ini.

Tabel 7. Hasil Uji Multikolinearitas Model Volume Ekspor Biji Kakao Indonesia ke Malaysia

\begin{tabular}{|c|l|c|c|}
\hline \multirow{2}{*}{ No } & \multicolumn{1}{|c|}{ Variabel Independen } & \multicolumn{2}{c|}{ Collinierity Statistics } \\
\cline { 3 - 4 } & \multicolumn{1}{|c}{ Tolerance } & VIF \\
\hline 1. & Produksi biji kakao Indonesia &, 522 & 1,915 \\
\hline 2. & Volume impor biji kakao Malaysia &, 568 & 1,760 \\
\hline 3. & $\begin{array}{l}\text { Nilai tukar riil rupiah terhadap dollar Amerika } \\
\text { Serikat }\end{array}$ &, 500 & 1,999 \\
\hline 4. & $\begin{array}{l}\text { Harga riil eksporbiji kakao Indonesia ke } \\
\text { Malaysia }\end{array}$ &, 134 & 7,488 \\
\hline 5. & Harga riil pasar internasional biji kakao &, 439 & 2,277 \\
\hline 6. & $\begin{array}{l}\text { Dummy tarif ekspor biji kakao Indonesia ke } \\
\text { Malaysia }\end{array}$ &, 220 & 4,538 \\
\hline
\end{tabular}

Sumber: Data Sekunder (Diolah) 
Berdasarkan hasil uji multikolinearitas yang telah dilakukan pada Tabel 7 menunjukkan bahwa nilai VIF dari masing-masing variabel bebas (produksi biji kakao Indonesia, volume impor biji kakao Malaysia, nilai tukar rupiah terhadap dollar Amerika Serikat, harga riil ekspor biji kakao Indonesia ke Malaysia, harga riil biji kakao Indonesia, dan dummy tarif ekspor biji kakao Indonesia ke Malaysia) bernilai kurang dari 10 (VIF $<10$ ), sehingga dapat disimpulkan bahwa model volume ekspor biji kakao Indonesia ke Malaysia yang dihasilkan dalam penelitian ini tidak terdapat masalah multikolinearitas.

\section{Uji Heteroskedastisitas}

Salah satu cara untuk mendeteksi masalah heteroskedastisitas dalam suatu model penelitian adalah dengan melihat hasil scatterplot. Hasil uji heteroskedastisitas dengan scatterplot pada model volume ekspor biji kakao Indonesia ke Malaysia dapat dilihat pada berikut ini.

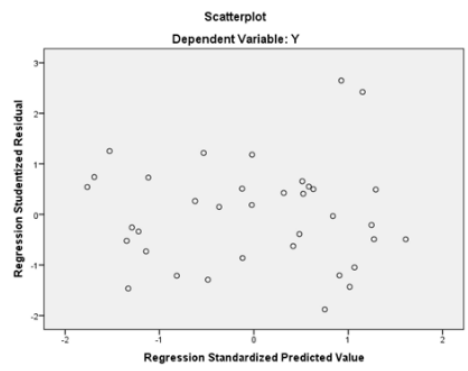

Gambar Hasil Uji Heteroskedastisitas Model Volume Ekspor Biji Kakao Indonesia ke Malaysia.

Berdasarkan hasil uji heteroskedastisitas dengan scatterplot pada Gambar 20 menunjukkan bahwa titik-titik hasil pengolahan data antara ZPRED dan SRESID menyebar di bawah maupun di atas titik origin (angka 0) pada sumbu Y dan tidak mempunyai pola yang teratur. Oleh karena itu dapat disimpulkan bahwa model volume ekspor biji kakao Indonesia ke Malaysia tidak terdapat masalah heteroskedastisitas.

\section{Uji Autokorelasi}

Mendeteksi adanya autokorelasi atau tidak dalam model volume ekspor biji kakao Indonesia ke Malaysia yaitu dengan menggunakan nilai DurbinWatson (DW). Berikut merupakan tabel hasil pengujian autokorelasi Durbin-Watson (DW) dalam penelitian di mana nilai $\mathrm{k}=6, \mathrm{n}=36$, tingkat signifikansi $(\alpha)=5 \%$.

Tabel 8. Hasil Uji Autokorelasi Model Volume Ekspor Biji Kakao Indonesia ke Malaysia

\begin{tabular}{|c|c|c|c|c|c|}
\hline Model & $\mathrm{R}$ & $R$ Square & $\begin{array}{c}\text { Adjusted } R \\
\text { Square }\end{array}$ & $\begin{array}{c}\text { Std. Errorof } \\
\text { the Estimate }\end{array}$ & $\begin{array}{c}\text { Durbin- } \\
\text { Watson }\end{array}$ \\
\hline 1 &, $802^{\mathrm{a}}$ &, 642 &, 569 & 7,41948 & 1,923 \\
\hline
\end{tabular}

Sumber: Data Sekunder (Diolah) 
Berdasarkan hasil uji atau tidaknya autokorelasi dapat autokorelasi pada Tabel 8 dapat diketahui nilai Durbin-Watson (DW) dalam model volume ekspor biji kakao Indonesia ke Malaysia adalah sebesar 1,923, untuk dapat mengetahui ada

\begin{tabular}{|c|c|c|c|c|c|}
\hline \multicolumn{2}{|c|}{$\begin{array}{c}\text { Autokorelasi } \\
\text { positif }\end{array}$} & \multirow{2}{*}{\begin{tabular}{l}
\multicolumn{1}{c}{ tanpa } \\
kesimpula \\
n \\
\\
\\
\\
\\
$\mathrm{d}$
\end{tabular}} & \multirow{2}{*}{$\begin{array}{c}\text { Nilai DW } \\
\text { 1,923 tidak } \\
\text { terjadi } \\
\text { autokorelasi } \\
4-\mathrm{d}_{\mathrm{U}}\end{array}$} & \multirow{2}{*}{$\begin{array}{c}\begin{array}{c}\text { Tanpa } \\
\text { kesimpulan }\end{array} \\
4-\mathrm{d}_{\mathrm{L}}\end{array}$} & \multirow{2}{*}{$\begin{array}{l}\begin{array}{c}\text { Autokorelasi } \\
\text { negatif }\end{array} \\
\end{array}$} \\
\hline 0 & $\begin{array}{l}d \\
L\end{array}$ & & & & \\
\hline & $\begin{array}{l}1,11 \\
44\end{array}$ & 1,8764 & 2,1236 & 2,8856 & \\
\hline
\end{tabular}

Sumber: Data Sekunder (Diolah) Keterangan: Taraf Nyata $(\alpha)$ Lima Persen

Berdasarkan Tabel 9 menunjukkan bahwa nilai DurbinWatson (DW) sebesar 1,923 berada di antara dU dan 4-dU. Hal ini menunjukkan bahwa tidak terjadi gangguan autokorelasi pada model volume ekspor biji kakao Indonesia ke Malaysia. Ini berarti variabel bebas (produksi biji kakao Indonesia, volume impor biji kakao Malaysia, nilai tukar riil rupiah terhadap dollar Amerika Serikat, harga riil ekspor biji kakao Indonesia ke Malaysia, harga riil pasar internasional biji kakao, dan dummy tarif ekspor biji kakao Indonesia ke Malaysia) tidak terganggu atau tidak terpengaruhi oleh variabel pengganggu sehingga dapat disimpulkan bahwa dalam model volume ekspor biji kakao Indonesia ke Malaysia tidak terjadi masalah autokorelasi.

\section{Uji Normalitas}

Uji normalitas dapat dilakukan dengan menggunakan analisa normal probability plot yaitu dengan melihat penyebaran data pada grafik Normal P-P plot. Regression Standardized dilihat pada Tabel 9 berikut ini. Tabel 9. Hasil Pengujian Ada Tidaknya Autokorelasi dengan Uji Durbin-Watson 
diagonal P-Plot sehingga data pada model volume ekspor biji kakao Indonesia ke Malaysia memenuhi asumsi normalitas. Menurut Sunyoto (2010:108) suatu data dikatakan berdistribusi normal jika garis data riil mengikuti garis diagonal. Maka dapat disimpulkan bahwa residual dalam model volume ekspor biji kakao Indonesia ke Malaysia terdistribusi secara normal.

\section{Hasil Pengujian Hipotesis}

Uji hipotesis dapat dilakukan dengan melakukan pengujian parameter model regresi linear berganda (uji t dan uji F) serta pengujian koefisien determinasi (R2).

\section{Uji F (Uji Simultan)}

Uji F statistik digunakan untuk mengetahui apakah variabel-variabel bebas (produksi biji kakao Indonesia, volume impor biji kakao Malaysia, nilai tukar riil rupiah terhadap dollar Amerika Serikat, harga riil ekspor biji kakao Indonesia ke Malaysia, harga riil pasar internasional biji kakao, dan dummy tarif ekspor biji kakao Indonesia ke Malaysia) pada penelitian secara simultan (bersamasama) berpengaruh nyata terhadap variabel terikat (volume ekspor biji kakao Indonesia ke Malaysia) pada tingkat kepercayaan $95 \%$ atau pada taraf nyata $(\alpha)$ sebesar $5 \%$.

Berikut merupakan hasil uji $\mathrm{F}$ dalam model volume ekspor biji kakao Indonesia ke Malaysia:

Tabel 10. Hasil Uji F (Uji Simultan) Model Volume Ekspor Biji Kakao Indonesia ke Malaysia

\begin{tabular}{|l|l|l|l|l|l|}
\hline \multirow{2}{*}{$\begin{array}{l}\text { Model } \\
1 \quad \text { Regression }\end{array}$} & $\begin{array}{l}\text { Sum of } \\
\text { Resuares }\end{array}$ & df & $\begin{array}{l}\text { Mean } \\
\text { Resuare }\end{array}$ & F & Sig. \\
\cline { 2 - 6 } & 2868,880 & 6 & 478,147 & 8,686 &, $000 \mathrm{~b}$ \\
& 1596,410 & 29 & 55,049 & & \\
\hline
\end{tabular}

Sumber: Data Sekunder (Diolah)

Keterangan: Taraf Nyata $(\alpha)$ Lima Persen

Berdasarkan Tabel 10 menunjukkan bahwa hasil uji $\mathrm{F}$ dengan tingkat signifikansi 0,05 dapat diketahui bahwa nilai probabilitas $\mathrm{F}$ sebesar 0,000 yang berarti nilai tersebut berada di bawah nilai signifikansi $(0,000<0,05)$ maka dapat disimpulkan bahwa dalam model volume ekspor biji kakao Indonesia ke Malaysia secara simultan atau bersama-sama variabel bebas (produksi biji kakao Indonesia, volume impor biji kakao Malaysia, nilai tukar riil rupiah terhadap dollar Amerika Serikat, harga riil ekspor biji kakao Indonesia ke Malaysia, harga riil pasar internasional biji kakao, dan dummy tarif ekspor biji kakao Indonesia ke Malaysia) memiliki pengaruh yang signifikan terhadap variabel terikatnya (volume ekspor biji kakao Indonesia ke Malaysia).

Selain melihat nilai probabilitas $\mathrm{F}$ (P-value), untuk pengujian secara simultan atau secara bersama-sama juga dapat dilihat dari nilai $F$ hitungnya. Hasil dari uji $\mathrm{F}$ diketahui bahwa F-hitung adalah sebesar 8,686 dengan degree of freedom (df) $=\mathrm{k}-1=7-1=6$ dan derajat bebas penyebut $(\mathrm{df} 2)=\mathrm{n}-\mathrm{k}=36-7=29$, dimana $\mathrm{k}$ adalah jumlah variabel bebas 
dan terikat dan $\mathrm{n}$ adalah jumlah observasi/sampel pembentu regresi. Berdasarkan tabel distribusi $\mathrm{F}$ (tabel bantuan jika menggunakan statistik uji F) diperoleh F-tabel sebesar 2,43. Jika dibandingkan antara Fhitung dan F-tabel, maka nilai Fhitung $(8,686)$ lebih besar dari pada Ftabel $(2,43)(8,686>2,43)$, sehingga dapat disimpulkan bahwa secara simultan atau bersama-sama variabel bebas (produksi biji kakao Indonesia, volume impor biji kakao Malaysia, nilai tukar riil rupiah terhadap dollar Amerika Serikat, harga riil ekspor biji kakao Indonesia ke Malaysia, harga riil pasar internasional biji kakao, dan dummy tarif ekspor biji kakao Indonesia ke Malaysia) memiliki pengaruh yang signifikan terhadap variabel terikatnya (volume ekspor biji kakao Indonesia ke Malaysia).

\section{Uji t (Uji Parsial)}

Uji t statistik digunakan untuk mengetahui apakah koefisien masingmasing variabel bebas (produksi biji kakao Indonesia, volume impor biji kakao Malaysia, nilai tukar riil rupiah terhadap dollar Amerika Serikat, harga riil ekspor biji kakao Indonesia ke Malaysia, harga riil pasar internasional biji kakao, dan dummy tarif ekspor biji kakao Indonesia ke Malaysia) secara parsial (individu) memberikan pengaruh yang signifikan terhadap variabel terikat (volume ekspor biji kakao Indonesia ke Malaysia).

Hasil Uji t (Uji Parsial) Model Volume Ekspor Biji Kakao Indonesia ke Malaysia

\begin{tabular}{|c|r|r|r|r|r|}
\hline \multirow{2}{*}{ Model } & \multicolumn{2}{|c|}{$\begin{array}{c}\text { Unstandardized } \\
\text { Coefficients }\end{array}$} & \multicolumn{1}{c|}{$\begin{array}{c}\text { Standardized } \\
\text { Coefficients }\end{array}$} & \multirow{2}{*}{$\mathrm{t}$} & \multirow{2}{*}{ Sig. } \\
\cline { 2 - 3 } & \multicolumn{1}{|c|}{$\mathrm{B}$} & Std. Error & \multicolumn{1}{|c|}{ Beta } & & \\
\hline 1 (Constant) & $-36,237$ & 31,294 & & $-1,158$ &, 256 \\
\hline $\mathrm{X}_{1}$ &, 194 &, 168 &, 178 & 1,158 &, 256 \\
\hline $\mathrm{X}_{2}$ &, 039 &, 096 &, 060 &, 404 &, 689 \\
\hline $\mathrm{X}_{3}$ &,- 002 &, 001 &,- 188 & $-1,196$ &, 241 \\
\hline $\mathrm{X}_{4}$ &, 001 &, 000 &, 670 & 2,205 &, 036 \\
\hline $\mathrm{X}_{5}$ &, 001 &, 000 &, 611 & 3,644 &, 001 \\
\hline $\mathrm{X}_{\mathrm{D}}$ & 2,326 & 5,343 &, 103 &, 435 &, 666 \\
\hline
\end{tabular}

Sumber: Data Sekunder (Diolah)

Keterangan: Taraf Nyata $(\alpha)$ Lima Persen

Keterangan:

$\mathrm{X} 1$ = Produksi biji kakao di Indonesia

$\mathrm{X} 2$ = Volume impor biji kakao Malaysia

X3 = Nilai tukar riil rupiah terhadap dollar Amerika Serikat

$\mathrm{X} 4$ = Harga riil ekspor biji kakao Indonesia ke Malaysia

X5 = Harga riil pasar internasional biji kakao
$\mathrm{XD}=$ Dummy tarif ekspor biji kakao Indonesia ke Malaysia

Berdasarkan table di atas dapat diketahui t-hitung yang diperoleh dari masing- masing variabel. Kemudian perlu diketahui nilai t-tabel yang akan digunakan. Nilai t-tabel tergantung pada besarnya degree of freedom (df) dan tingkat signifikansi yang digunakan. Tingkat signifikansi yang 
digunakan pada penelitian ini adalah sebesar $5 \%$ dengan nilai $\mathrm{df}=\mathrm{n}-\mathrm{k}=$ $36-7=29$, maka diperoleh nilai $\mathrm{t}$ tabel adalah sebesar 1,69913.

\section{Uji Koefisien Determinasi (R2)}

Koefisien determinasi (R2) digunakan untuk mengetahui sejauh mana ketepatan atau kecocokan garis regresi yang terbentuk dalam mewakili kelompok data hasil observasi. Koefisien determinasi menggambarkan bagian dari variasi total yang dapat diterangkan oleh model.

Tabel 12. Hasil Uji Koefisien Determinasi (R2) Model Volume Ekspor Biji KakaoIndonesia ke Malaysia

\begin{tabular}{|c|c|c|c|c|}
\hline Model & $\mathrm{R}$ & $R$ Square & $\begin{array}{c}\text { Adjusted } R \\
\text { Square }\end{array}$ & $\begin{array}{c}\text { Std. Errorof the } \\
\text { Estimate }\end{array}$ \\
\hline 1 &, $802^{\mathrm{a}}$ &, 642 &, 569 & 7,41948 \\
\hline
\end{tabular}

Sumber: Data Sekunder (Diolah)

Keterangan: Taraf Nyata $(\alpha)$ Lima Persen

Berdasarkan Tabel 12 diperoleh nilai koefisien determinasi ( $\mathrm{R}$ square) sebesar 0,642. Hal ini berarti bahwa variabel terikat (volume ekspor biji kakao Indonesia ke Malaysia (Y)) mampu dijelaskan oleh variabel-variabel bebas dalam penelitian ini yang meliputi; produksi biji kakao Indonesia (X1), volume impor biji kakao Malaysia (X2), nilai tukar riil rupiah terhadap dollar Amerika Serikat (X3), harga riil ekspor biji kakao Indonesia ke Malaysia (X4), harga riil pasar internasional biji kakao (X5), dan dummy tarif ekspor biji kakao Indonesia ke Malaysia (XD) sebesar $64,2 \%$, sedangkan $35,8 \%$ lainnya dijelaskan oleh variabel- variabel bebas lain di luar model (yang diteliti).

\section{Persamaan Regresi Linear Berganda}

Berdasarkan hasil analisis regresi linear berganda pada Tabel 11, maka model volume ekspor biji kakao
Indonesia ke Malaysia diperoleh persamaan regresi sebagai berikut:

$\mathrm{Y}=-36,237+0,194 \mathrm{X} 1+0,039 \mathrm{X} 2-$ $0,002 \times 3+0,001 \mathrm{X} 4+0,001 \mathrm{X} 5+2,326$

$\mathrm{XD}+\mathrm{e}$

Keterangan:

$\mathrm{Y}=$ Volume ekspor biji kakao Indonesia ke Malaysia

$\mathrm{X} 1$ = Produksi biji kakao Indonesia

$\mathrm{X} 2$ = Volume impor biji kakao Malaysia

X3 = Nilai tukar riil rupiah terhadap dollar Amerika Serikat

$\mathrm{X} 4=$ Harga riil ekspor biji kakao Indonesia ke Malaysia

X5 = Harga riil pasar internasional biji kakao

$\mathrm{XD}=$ Dummy tarif ekspor biji kakao Indonesia ke Malaysia

$\mathrm{e}=$ error

Faktor-Faktor

yang

Mempengaruhi Volume Ekspor Biji Kakao Indonesia ke Malaysia Tahun 2005 - 2013

Faktor-faktor

mempengaruhinya merupakan 
variabel bebas dalam penelitian dengan enam variabel bebas yaitu; produksi biji kakao Indonesia (000 ton), volume impor biji kakao Malaysia (000 ton), nilai tukar riil rupiah terhadap dollar Amerika (Rp/US\$), harga riil ekspor biji kakao Indonesia ke Malaysia (US\$/000 ton), harga riil pasar internasional biji kakao (US\$/000 ton), dan dummy tarif ekspor biji kakao Indonesia ke Malaysia (\%).

Hasil penelitian model volume ekspor biji kakao Indonesia ke Malaysia menunjukkan faktor-faktor yang mempengaruhi volume ekspor biji kakao Indonesia ke Malaysia dalam penelitian ini sebagai berikut:

\section{Produksi Biji Kakao Indonesia (X1) \\ Hasil regresi linear berganda} model volume ekspor biji kakao Indonesia ke Malaysia menunjukkan bahwa tanda koefisien produksi biji kakao di Indonesia adalah positif.

Berdasarkan hasil regresi linear berganda pada model volume ekspor biji kakao Indonesia ke Malaysia, variabel produksi biji kakao Indonesia memiliki nilai koefisien regresi sebesar 0,194.

Berdasarkan hasil uji t yang telah dilakukan, variabel produksi biji kakao Indonesia dalam model volume ekspor biji kakao Indonesia ke Malaysia tidak berpengaruh secara signifikan atau tidak berpengaruh nyata pada taraf nyata $(\alpha)$ lima persen terhadap volume ekspor biji kakao Indonesia ke Malaysia. Ketidaksesuaian tersebut diduga kualitas biji kakao Indonesia yang rendah dikarenakan tidak melalui proses fermentasi terlebih dahulu, sehingga tidak semua biji kakao yang diproduksi Indonesia dapat dijual di pasar ekspor Malaysia.
2. VolumeImpor Biji Kakao

Hasil regresi linear berganda model volume ekspor biji kakao Indonesia ke Malaysia menunjukkan bahwa tanda koefisien volume impor biji kakao Malaysia adalah positif.

Berdasarkan hasil analisis regresi linear berganda pada model volume ekspor biji kakao Indonesia ke Malaysia, variabel volume impor biji kakao Malaysia memiliki nilai koefisien regresi sebesar 0,039.

Berdasarkan hasil uji $\mathrm{t}$ yang telah dilakukan, variabel volume impor biji kakao Malaysia dalam model volume ekspor biji kakao Indonesia ke Malaysia tidak berpengaruh secara signifikan atau tidak berpengaruh nyata pada taraf nyata $(\alpha)$ lima persen terhadap volume ekspor biji kakao Indonesia ke Malaysia. Apabila kebutuhan biji kakao di Malaysia pada tahun tersebut tinggi namun volume ekspor biji kakao Indonesia ke Malaysia di tahun yang sama mengalami penurunan, maka untuk memenuhi kebutuhan biji kakao, Malaysia melakukan impor biji kakao dari negara lain.

\section{Nilai Tukar Riil Rupiah terhadapDollar \\ AmerikaSerikat(X3) \\ Hasil regresi linear berganda} model volume ekspor biji kakao Indonesia ke Malaysia menunjukkan bahwa tanda koefisien nilai tukar riil rupiah terhadap dollar Amerika Serikat adalah negatif.

Berdasarkan hasil analisis regresi linear berganda pada model volume ekspor biji kakao Indonesia ke Malaysia, variabel nilai tukar riil rupiah terhadap dollar Amerika Serikat memiliki koefisien regresi sebesar -0,002. Variabel nilai tukar riil rupiah terhadap dollar Amerika 
Serikat dalam model volume ekspor biji kakao Indonesia ke Malaysia tidak berpengaruh secara signifikan atau berpengaruh tidak nyata pada taraf nyata $(\alpha)$ lima persen terhadap volume ekspor biji kakao Indonesia ke Malaysia.

4. Harga Riil Ekspor Biji Kakao Indonesia ke Malaysia (X4)

Hasil regresi linear berganda model volume ekspor biji kakao Indonesia ke Malaysia menunjukkan bahwa tanda koefisien harga riil ekspor biji kakao Indonesia ke Malaysia adalah positif.

Berdasarkan hasil analisis regresi linear berganda pada model volume ekspor biji kakao Indonesia ke Malaysia, variabel harga riil ekspor biji kakao Indonesia ke Malaysia memiliki koefisien regresi sebesar 0,001.

Berdasarkan hasil uji $\mathrm{t}$ yang telah dilakukan, variabel harga riil ekspor biji kakao Indonesia ke Malaysia dalam model volume ekspor biji kakao Indonesia ke Malaysia berpengaruh secara signifikan/nyata pada taraf nyata $(\alpha)$ lima persen terhadap volume ekspor biji kakao Indonesia ke Malaysia.

5. Harga riil pasar internasional biji kakao (X5)

Hasil regresi linear berganda model volume ekspor biji kakao Indonesia ke Malaysia menunjukkan bahwa tanda koefisien harga riil pasar internasional biji kakao adalah positif. Berdasarkan hasil analisis regresi linear berganda pada model volume ekspor biji kakao Indonesia ke Malaysia menunjukkan bahwa variabel harga riil pasar internasional biji kakao memiliki koefisien regresi sebesar 0,001 .
Berdasarkan hasil uji $\mathrm{t}$ yang telah dilakukan, variabel harga riil pasar internasional biji kakao dalam model volume ekspor biji kakao Indonesia ke Malaysia juga berpengaruh secara signifikan/nyata pada taraf nyata $(\alpha)$ lima persen terhadap volume ekspor biji kakao Indonesia ke Malaysia.

\section{Dummy Tarif Ekspor Biji Kakao Indonesia ke Malaysia (XD) \\ Berdasarkan hasil analisis} regresi linear berganda pada model volume ekspor biji kakao Indonesia ke Malaysia menunjukkan bahwa variabel dummy tarif ekspor biji kakao Indonesia ke Malaysia memiliki koefisien regresi sebesar2,326.

Berdasarkan hasil uji $\mathrm{t}$ yang telah dilakukan, variabel dummy tarif ekspor biji kakao Indonesia ke Malaysia tidak berpengaruh nyata terhadap volume ekspor biji kakao Indonesia ke Malaysia pada taraf nyata $(\alpha)$ lima persen. Kebijakan tarif ekspor yang telah ditetapkan oleh pemerintah bertujuan untuk menekan volume ekspor biji kakao Indonesia, sehingga dengan adanya tarif ekspor biji kakao diharapkan mampu menurunkan volume ekspor biji kakao Indonesia ke Malaysia.

\section{KESIMPULAN}

Berdasarkan hasil dan pembahasan yang dilakukan dalam penelitian dengan judul "Analisis Faktor-Faktor yang Mempengaruhi Volume Ekspor Biji Kakao Indonesia ke Malaysia" dalam kurun waktu 2005 - 2013 dapat disimpulkan beberapa hal sebagai berikut:

1. Faktor - faktor yang mempengaruhi volume ekspor 
biji kakao Indonesia ke Malaysia yang telah dianalisis dalam penelitian ini adalah produksi biji kakao Indonesia, volume impor biji kakao Malaysia, nilai tukar riil rupiah terhadap dollar Amerika Serikat, harga riil ekspor biji kakao Indonesia ke Malaysia, harga riil pasar internasional biji kakao, dan dummy tarif ekspor biji kakao Indonesia ke Malaysia.

2. Hasil penelitian ini menunjukkan nilai koefisien determinasi (R2) sebesar 0,642. Artinya bahwa volume eskpor biji kakao Indonesia ke Malaysia mampu dijelaskan oleh variabel-variabel bebas (produksi biji kakao Indonesia, volume impor biji kakao Malaysia, nilai tukar riil rupiah terhadap dollar Amerika Serikat, harga riil ekspor biji kakao Indonesia ke Malaysia, harga riil biji kakao intenasional, dan dummy tarif ekspor biji kakao Indonesia ke Malaysia) sebesar $64,2 \%$ sedangkan $35,8 \%$ dijelaskan oleh variabel- variabel bebas lainnya. Hasil uji $\mathrm{F}$ menunjukkan secara simultan (bersama- sama) variabel bebas yang diteliti memiliki pengaruh yang signifikan terhadap variabel terikatnya. Adapun faktor-faktor yang paling berpengaruh secara signifikan/nyata terhadap volume ekspor biji kakao Indonesia ke Malaysia dengan taraf nyata $(\alpha)$ lima persen adalah harga riil ekspor biji kakao Indonesia ke Malaysia dan harga riil pasar internasional biji kakao.

\section{DAFTAR PUSTAKA}

Algifari. 2013. Analisis Regresi Teori, Kasus, dan Solusi.
Yogyakarta:

BPFE-

Yogyakarta.

Azwar, Saifuddin. 2013. Metode Penelitian. Yogyakarta:

Pustaka Pelajar.

Badan Pusat Statistik (BPS). 2014. Data Ekspor Biji Coklat Menurut Negara Tujuan Utama, 2002 - 2013. 1 Halaman.

http://www.bps.go.id//.

Diakses pada 16 Mei 2015. Pukul 12:48 WIB.

Badan Pusat Statistik (BPS). 2015. Data Indeks Harga Konsumen Indonesia, 2005-2014. 1 Halaman.

http://www.bps.go.id//.

Diakses pada 18 November 2015. Pukul 10:58 WIB.

Bank Indonesia. 2014. Data Nilai Tukar Rupiah. 1 Halaman. http://www.bi.go.id//. Diakses pada 12 November 2015. Pukul 17:49 WIB.

Basri, Faisal dan Haris Munandar. 2010. Dasar-dasar Ekonomi Internasional.

Jakarta: Kencana Prenada Media Group.

Department of Statistic Malaysia. 2015. Data Produksi Biji Kakao Malaysia. 1 Halaman. http://www.statistics.gov.my/ /. Diakses pada 20 Januari 2016. Pukul 15:32 WIB.

- Data Konsumsi Biji Kakao Malaysia.1 Halaman. http://www.statistics.gov.my/ /. Diakses pada 20 Januari 2016. Pukul 15:36 WIB. 
Direktorat Jenderal Perkebunan. 2014. Statistik Perkebunan Indonesia Kakao. Jakarta: Kementerian Pertanian Republik Indonesia.

Food and Agriculture Organization (FAO). 2015. Data Luas Areal Kakao Dunia. 1 Halaman. http://www.fao.org//. Diakses pada 19 Januari 2016. Pukul13:25 WIB.

\section{Data Produksi Kakao} Dunia.1 Halaman. http://www.fao.org//. Diakses pada 19 Januari 2016. Pukul13:30 WIB.

Data Ekspor Biji Kakao Dunia.1 Halaman. http://www.fao.org//. Diakses pada 19 Januari 2016. Pukul13:35 WIB.

Kakao Dunia.1 Halaman. http://www.fao.org//. Diakses pada 19 Januari 2016. Pukul13:40 WIB.

Ghozali, Imam. 2006. Aplikasi Analisis Multivariate dengan Program SPSS. Semarang: Badan Penerbit Universitas Diponegoro.

Halwani, R Hendra. 2002. Ekonomi Internasional dan Globalisasi Ekonomi. Jakarta: Ghalia Indonesia.

Heryanto dan Lukman. 2008. Statistik Ekonomi. Ciputat Jakarta Selatan: Lembaga Penelitian Universitas Islam
NegeriSyarif Hidayatullah Jakarta.

Indikator Ekonomi. 2015. Data Indeks Harga Konsumen Amerika Serikat, 2005 2013. 1 Halaman. http://www.tradingeconomics .com//. Diakses pada 18November 2015. Pukul 11.15 WIB.

Data

Indeks Harga Konsumen Malaysia, 2005 - 2013. 1 Halaman.

http://www.tradingeconomics .com//. Diakses pada 18 November 2015. Pukul 11.15 WIB.

International Cocoa Organization (ICCO). 2012. The World Cocoa Economy: Past and Present. [E-Book]. London: International Cocoa Organization.

- 2014. Data Harga Biji Kakao Internasional. 9 Halaman. http://www.icco.org//.

Diakses pada 9November 2015. Pukul 19.37 WIB.

KBRI Kuala Lumpur. 2011. Market Brief: Penetrasi Pasar Kakao Malaysia. 25 Halaman.http://www.kbrikual alumpur.org//. Diakses pada 3 Juni 2015. Pukul 12:33 WIB.

Kementerian Keuangan Republik Indonesia. 2012. Kajian Perkembangan Perekonomian Kakao Nasional Pasca Pengenaan Bea Keluar Biji Kakao.8 Halaman. http://www.fiskal.depkeu.go.i 
d//. Diakses pada 27 Juni 2015. Pukul 15:20 WIB.

Kementerian Perdagangan Republik Indonesia. 2015. Data Ekspor Sepuluh Komoditi Utama Negara Indonesia, 2010 2015. 1 Halaman. http://www.kemendag.go.id//. Diakses pada 5 Februari 2016. Pukul 16.05 WIB.

.2016. Realisasi Ekspor Biji Kakao Indonesia ke Dunia, 2004 2015. 2 Halaman Microsoft Excel. 21 Maret2016.

Komisi Kakao Indonesia. 2006. Direktori Dan Revitalisasi Agribisnis Kakao Indonesia. Jakarta: Komisi Kakao Indonesia.

Lukman. 2007. Pengantar Mikro Ekonomi. Ciputat Jakarta Selatan: Lembaga Penelitian UIN Jakarta dengan UIN Jakarta Press.

Malaysian Cocoa Board. 2014. Data Harga Biji Kakao Malaysia. 9 Halaman. http://www.koko.gov.my//. Diakses pada 15 Januari 2016. Pukul 20:39WIB.

Mankiw, N Gregory, Euston Quah, dan Peter Wilson. 2012. Pengantar Ekonomin Makro. Jakarta: Salemba Empat.

. Pengantar Ekonomi Mikro. Jakarta: Salemba Empat.

Masyhuri. 2007. Ekonomi Mikro. Malang: UIN-Malang Press.

Muhidin, Sambas Ali dan Maman Abdurrahman. 2007. Analisis Korelasi, Regresi, dan Jalur dalam Penelitian. Bandung: CV Pustaka Setia.

Murni, Asfia. 2006. Ekonomi Makro. Bandung: PT Refika Aditama

Nopirin. $\quad 1999 . \quad$ Ekonomi Internasional Edisi Ketiga. Yogyakarta: BPFE-

Yogyakarta

Nurahmat, Dady. 2011. Analisis Faktor-Faktor Yang Memengaruhi Penawaran Ekspor CPO Indonesia Ke India (Periode Analisis Tahun 1989-2010) [Skripsi]. Bogor: Fakultas Ekonomi dan Manajemen Institut Pertanian Bogor.

Pambudi, Archibald Damar. 2011. Analisis Faktor-Faktor Yang Mempengaruhi Ekspor Biji Kakao Indonesia Ke Malaysia Dan Singapura [Skripsi]. Semarang: Fakultas Ekonomi Universitas Diponegoro.

Pindyck, Robert S., Daniel L. Rubinfeld. 2007. Mikroekonomi Edisi Keenam Jakarta: PT Indeks.

Pusat Penelitian Kopi dan Kakao Indonesia. 2010. Budi Daya Kakao. Jakarta: AgroMedia Pustaka

Putra, Dinan Arya. 2013. Analisis Faktor-Faktor Yang Mempengaruhi Ekspor Tembakau Indonesia ke Jerman [Skripsi]. Semarang: Fakultas Ekonomi Universitas Negeri Semarang.

Rahardja, Prathama, Mandala Manurung. 2008. Pengantar 
Ilmu Ekonomi

(Makroekonomi \&

Mikroekonomi) Edisi Ketiga.

Jakarta: Lembaga Penerbit

Fakultas Ekonomi Universitas

Indonesia

Rasul, Agung Abdul, Nuryadi Wijiharjono, dan Tupi Setyowati. 2013. Ekonomi Mikro Edisi Kedua. Jakarta: Penerbit Mitra Wacana Media.

Ridwan. 2010. Metode dan Teknik Menyusun Tesis, Cetakan ke8. Bandung: Alfabeta.

Rosadi, Dedi. 2012. Ekonometrika \& Analisis Runtun Waktu Terapan dengan EViews. Yogyakarta: CV Andi Offset.

Salvatore, Domonick. 1997. Ekonomi Internasional Edisi Kelima. Jakarta: Erlangga.

Sasono, Herman Budi. 2013. Manajemen Ekspor dan Perdagangan Internasional. Yogyakarta: CV. Andi Offset.

Setiawan dan Dwi Endah Kusrini. 2010. Ekonometrika. Yogyakarta. CV. Andi Offset.

Siregar, Sofiyan. 2010. Statistik Deskriptif untuk Penelitian. Jakarta. PT Raja Grafindo Indonesia.

Sitanggang, Veronika Eka. 2009. Analisis Faktor-Faktor Yang Mempengaruhi Permintaan Ekspor Biji Kakao Indonesia di Malaysia, Singapura, dan Thailand dalam Skema CEFT-AFTA [Skripsi].
Bogor: Fakultas Ekonomi dan Manajemen Institut Pertanian Bogor.

Soekartawi. 2002. Prinsip Dasar Ekonomi Pertanian Teori dan Aplikasi Edisi Revisi 2002. Jakarta: PT RajaGrafindo Persada.

2003. Agribisnis Teori dan Aplikasi. Jakarta: PT Raja Grafindo Persada.

Sujianto, Agus Eko. 2009. Aplikasi Statistik dengan SPSS 16.0. Jakarta: PT. Prestasi Pustakarya.

Sukirno, $\quad$ Sadono. 2010. Makroekonomi Teori Pengantar Edisi Ketiga. Jakarta: Rajawali Pres.

2009. Statistik Ekonomi Induktif Metode Pengujian \&Pengambilan Keputusan. Jakarta: PT Macanan Jaya Cemerlang.

Sunyoto, Danang. 2010. Uji KHI Kuadrat dan Regresi Untuk Penelitian.Yogyakarta : Graha Ilmu.

Suparmoko. 1998. Pengantar Ekonomika Makro. Yogyakarta. BPFE.

Suyatno, Bagong \& Sutinah. 2005. Metode Penelitian Sosial edisi ketiga. Prenada Media Group: Jakarta.

Uncomtrade. 2015. Data Impor Biji Kakao Malaysia. 1 Halaman. http://www.comtrade.un.org// - Diakses pada 10 Januari 2016. Pukul 16:24 WIB. 
Wahyudi, T, T.R. Panggabean, dan Pujiyanto. 2009. Kakao Manajemen Agribisnis dari Hulu hingga Hilir. Jakarta: Penebar Swadaya.

Wahyudi, Teguh, Pujiyanto, dan Miswani. 2015. Kakao (Sejarah, Botani, Proses Produksi, Penglahan, dan Perdagangan). Yogyakarta: Gadjah Mada University Press.

Widyatutik dan Reni Kristina Arianti. 2013. Strategi Kebijakan Mutu dan Standar Produk Ekspor dalam Meningkatkan Daya Saing (Studi Kasus Produk Ekspor Biji Kakao) [Jurnal]. Bogor: Fakultas Ekonomi dan Manajemen Institut Pertanian Bogor.

Yuwono, prapto. 2005. Pengantar Ekonometri. Yogyakarta: CVAndi Offset.

* Alamat Korespondensi:

lilis.imamah@uinjkt.ac.id 
Jurnal Agribisnis, Vol. 11, No. 5, Desember 2017, [161- 182]

ISSN : 1979-0058 